\title{
Growth performance of post-weaned Holstein male calves accelerated by branched-chain volatile fatty acids addition with up-regulated hepatic $m T O R$ expression via insulin and insulin-like growth factor-1 (IGF-1) signalling pathway
}

\author{
Y. Liu, C. Wang, G. Guo, W. Huo, Y. Zhang, C. Pei, Q. Liu and S. Zhang \\ Shanxi Agricultural University, College of Animal Science and Veterinary Medicine, Taigu, 030801, Shanxi, P. R. China
}

KEY WORDS: branched chain fatty acids, calves, dairy cattle, gene expression, growth rate, hormone secretion, liver

$\begin{array}{lr}\text { Received: } & 7 \text { October } 2018 \\ \text { Revised: } & 25 \text { July } 2019 \\ \text { Accepted: } & 16 \text { September } 2019\end{array}$

Accepted: 16 September 2019

${ }^{1}$ Corresponding author:

e-mail: liuqiangabc@163.com

\begin{abstract}
The study evaluated the effects of branched-chain volatile fatty acids (BCVFA) addition on growth performance, ruminal fermentation, nutrient digestibility, hormone secretion and hepatic gene expression in dairy calves. Thirty-six Holstein male calves ( $45 \pm 3.5$ days of age; $56 \pm 1.8 \mathrm{~kg}$ body weight) were randomly assigned to four groups: control, low-BCVFA (LBC), mediumBCVFA (MBC) and high-BCVFA (HBC) with 0, 1.5, 3.0 and $4.5 \mathrm{~g}$ BCVFA per $\mathrm{kg}$ dietary dry matter (DM), respectively. Supplemental BCVFA was premixed into concentrate of the ration. DM intake and average daily gain (ADG) were increased, and feed conversion ratio was decreased in $\mathrm{MBC}$ and $\mathrm{HBC}$ groups in comparison to control one. In $\mathrm{MBC}$ and $\mathrm{HBC}$ groups ruminal $\mathrm{pH}$ and ammonia$\mathrm{N}$ were lower, whereas total volatile fatty acids concentration was higher than in control group. Acetate:propionate ratio and digestibility of DM, organic matter, crude protein, ether extract, neutral detergent fibre and acid detergent fibre were higher in $\mathrm{MBC}$ and $\mathrm{HBC}$ groups than in control one. Blood concentration of glucose, albumin, growth hormone releasing hormone, growth hormone (GH), insulin (INS) and insulin-like growth factor-1 (IGF-1), and hepatic mRNA abundance of GH, INS, IGF-1, receptors of GH, INS and IGF-1, mammalian target of rapamycin ( $m T O R)$, eukaryotic translation initiation factor $4 \mathrm{E}$-binding protein 1 and ribosomal protein S6 kinase were higher in MBC and $\mathrm{HBC}$ than in control group. It was indicated that BCVFA addition increased ADG by stimulating feed intake, ruminal fermentation, nutrient digestion and hepatic mTOR expression, and the optimum dose of BCVFA was $3.0 \mathrm{~g} / \mathrm{kg}$ DM under the current experimental conditions.
\end{abstract}

\section{Introduction}

The demand for beef in the market is still increasing, and therefore the part of beef production comes from dairy male calves. Thus studying the growth promoting mechanism of feed additives in dairy male calves is necessary. During the growth period, mammalian target of rapamycin (mTOR) plays a key role in regulating protein synthesis via activating through its downstream genes, eukaryotic translation initiation factor 4E-binding protein 1 (4EBP1) and ribosomal protein S6 kinase 
(S6K) (Lee et al., 2010; Pivonello et al., 2016). Some studies indicated that the mTOR signalling pathway could be activated by an increase in nutrient intake, insulin (INS) or insulin-like growth factor-1 (IGF-1), and this activation may contribute to muscle protein synthesis and weight gain in newborn pigs (Davis et al., 2000; Lee et al., 2010). The data suggested that the accelerated growth performance of post-weaned male calves with feed additives addition might be accompanied with an up-regulated hepatic $m T O R$ expression.

Ruminal branched-chain volatile fatty acids (valerate, isobutyrate, isovalerate and 2-methylbutyrate; BCVFA) derive from the degradation of feed protein, and in turn are used by microbes to synthesis their branched-chain amino acids, higher branched-chain fatty acids and aldehydes (Cummins and Papas, 1985). Dietary BCVFA supplementation reduced feed protein degradation, and spared amino acids and energy for microbial growth. In recent studies it was indicated that supplementation of BCVFA increased ruminal primary cellulolytic bacteria abundance, enzyme activity and microbial protein synthesis (Liu et al., 2014; Wang et al., 2015), and resulted in an increased ruminal total volatile fatty acids (VFA) concentration and nutrient digestibility in steers (Liu et al., 2008; 2009) or in post-weaned dairy calves (Wang et al., 2017). It was demonstrated that the secretions of INS and IGF-1were positively regulated by an increased feed intake or ruminal VFA concentration (Smith et al., 2002; Zhao and Sun, 2010). Zhao and Sun (2010) found that content of growth hormone (GH), INS and IGF-1 in blood as well as IGF-1 in the liver increased with increasing ruminal VFA infusion in sheep. Smith et al. (2002) reported that a higher plasma INS and IGF-1 and hepatic mRNA expression for GH receptor $(G H R)$ and $I G F-1$ were observed due to an increased nutrient intake in calves. In our previous studies we have found that plasma GH and IGF-1 were elevated, and an increased average daily gain (ADG) and dry matter (DM) intake were observed with 2-methylbutyrate or isobutyrate supplementation in dairy calves (Liu et al., 2016; Wang et al., 2017). It was deduced that the observed higher ADG in calves supplemented with BCVFA (Liu et al., 2016; Wang et al., 2017) might be accompanied with an up-regulated hepatic mTOR signalling pathway gene expression.

Based on the above, it was hypothesized that dietary BCVFA supplementation could stimulate hepatic $m T O R$ expression by promoting feed intake, ruminal fermentation and hormone secretion in calves. Therefore, the objective of the study was to evaluate the effects of BCVFA addition on DM intake, ADG, ruminal fermentation, nutrient digestibility, hormone secretion and hepatic gene expression in post-weaned dairy male calves.

\section{Material and Methods}

\section{Chemicals}

The BCVFA supplement was a mixture of isobutyrate, isovalerate and 2-methylbutyrate (analytical grade, 98.5\%, Yangxi Spice Factory, Guangdong, China) according to the ratio of 1:1:1.

\section{Animals}

Thirty-six Chinese Holstein male calves with $45 \pm 3.5$ days of age and $56 \pm 1.8 \mathrm{~kg}$ body weight (BW) were selected.

\section{Experimental design}

The experimental design and protocol were approved by the Animal Care and Use Committee of Shanxi Agriculture University (Shanxi, China). Calves were assigned randomly to four groups: control, low-BCVFA (LBC), medium-BCVFA (MBC) and high-BCVFA (HBC) with 0, 1.5, 3.0 and $4.5 \mathrm{~g}$ BCVFA per kg dietary DM, respectively. The study lasted 107 days, including a 15-day adaptation period followed by a 92-day sampling period.

\section{Animal feeding and management}

Calves were fed ad libitum a total mixed ration (TMR; Table 1). The TMR was formulated based on NRC recommendations for 50,100 and $150 \mathrm{~kg}$ dairy calves (NRC, 2001). The BCVFA was premixed into concentrate of the ration. Calves were housed in individual pens $(2.5 \times 3 \mathrm{~m})$ and fed twice a day at 07:00 and 19:00. Fresh water was available ad libitum.

\section{Sample collection}

Calves were weighed for two consecutive days on $60,90,120$ and 150 day of age at the same time relative to feeding. Offered feed and refusals were recorded daily through the experimental period to calculate DM intake. Samples of feed and refusals were collected once a week, dried in an oven at $55^{\circ} \mathrm{C}$ for $48 \mathrm{~h}$, and ground to pass a 1-mm screen with a cutter mill (110, Qingdao Ruixintai Instrument Co., Ltd., Qingdao, China) for chemical analysis.

From 134 to 149 day of age, twice a day calves received orally $2 \mathrm{~g}$ of chromic oxide in gelatin capsule per day per calf in two equal proportions at 7:00 and 19:00 as a digesta marker. Faecal samples 
Table 1. Ingredient and chemical composition of the basal diet, $\mathrm{g} / \mathrm{kg}$ dry matter

\begin{tabular}{lrrr}
\hline \multirow{2}{*}{ Indices } & \multicolumn{3}{l}{ Days of age } \\
\cline { 2 - 4 } & $45-90$ & $91-120$ & $121-152$ \\
\hline Ingredients & & & \\
maize silage & 200 & 250 & 300 \\
alfalfa hay & 200 & 200 & 200 \\
maize grain, ground & 315 & 310 & 310 \\
wheat bran & 30 & 30 & 30 \\
soybean meal & 175 & 130 & 80 \\
cottonseed cake & 40 & 40 & 40 \\
rapeseed meal & 20 & 20 & 20 \\
calcium carbonate & 5 & 5 & 5 \\
salt & 5 & 5 & 5 \\
dicalcium phosphate & 5 & 5 & 5 \\
mineral and vitamin mix & 5 & 5 & 5 \\
Chemical composition & & & \\
organic matter & 945.6 & 945.1 & 944.3 \\
crude protein & 195.3 & 170.5 & 160.2 \\
neutral detergent fibre & 260.2 & 274.3 & 290.6 \\
acid detergent fibre & 166.7 & 175.9 & 185.2 \\
Ca & 7.2 & 7.1 & 6.9 \\
$\mathrm{P}$ & 4.5 & 4.3 & 4.1 \\
\hline
\end{tabular}

${ }^{1}$ contained per kg of premix: IU: vit. A 600000 , vit. D 400 000; mg: vit. E 6 000, Co 48, Cu 1800, Fe 12 000, Mn 6 200, Zn 8 100, I 130, Se 60

(approximately $200 \mathrm{~g}$ wet weight) were collected from the rectum three times a day at various times ( $3 \mathrm{~h}$ intervals) from 139 to 149 day of age. At the end of the experiment, samples were thawed, composited by calf on an equal wet weight basis. After being dried at $55{ }^{\circ} \mathrm{C}$ for $48 \mathrm{~h}$ to constant weight, samples were ground to pass a 1-mm sieve for chemical analyses. Dry matter excreted in faeces was calculated by dividing chromium input (grams of chromium per day) by chromium concentration (grams of chromium per $\mathrm{kg}$ of DM) in the faeces (Ferret et al., 1999). Excretion of other nutrient in the faeces was calculated by multiplying DM flow by their concentration in faecal DM.

Ruminal fluid was sampled for two consecutive days on 105 and 150 day of age, $3 \mathrm{~h}$ after the morning feeding, via the esophagus using a stomach tube (1-cm outside diameter, $0.8-\mathrm{cm}$ inside diameter, $300-\mathrm{cm}$ length) connected to a vacuum pump (Speedivac 2, Edwards High Vacuum, Crawley, UK) from several sites within the rumen (Jacobson et al., 1957). Ruminal $\mathrm{pH}$ was immediately measured using an electric $\mathrm{pH}$ meter (PHS-3C, Shanghai Leijun Experimental Instrument Co., Ltd., Shanghai, China). Samples were then strained through four layers of cheesecloth. Five millilitres of filtrate were preserved by adding $1 \mathrm{ml}$ of $250 \mathrm{~g} / 1$ meta-phosphoric acid to determine VFA, and $5 \mathrm{ml}$ of filtrate were preserved by adding $1 \mathrm{ml}$ of $20 \mathrm{~g} / \mathrm{l}(\mathrm{w} / \mathrm{v}) \mathrm{H}_{2} \mathrm{SO}_{4}$ to determine $\mathrm{NH}_{3}-\mathrm{N}$. Samples were subsequently stored frozen at $-20{ }^{\circ} \mathrm{C}$ until analyses.

Blood samples were obtained on 106 and 151 day of age, $2 \mathrm{~h}$ after morning feeding, via the coccygeal vein using $10-\mathrm{ml}$ heparinized and unheparinized vacuum tubes. Blood samples were immediately placed on ice and transported to the laboratory to separate serum by centrifuging at $2000 \mathrm{~g}$ for $15 \mathrm{~min}$ at $4{ }^{\circ} \mathrm{C}$. All serum samples were stored frozen at $-20^{\circ} \mathrm{C}$ for half a month before analyses.

At 152 day of age, the liver was biopsied under local anaesthesia by blind percutaneous needle biopsy $(14 \mathrm{G} \times 152 \mathrm{~mm}$; Dispomed Witt oHG, Gelnhausen, Germany) (Gross et al., 2011). A portion of the liver samples (200 mg) were put in RNA stabilization reagent (RNAlater; Ambion, Applied Biosystems Inc., Austin, TX, USA), kept at $4{ }^{\circ} \mathrm{C}$ for $24 \mathrm{~h}$, and then stored at $-80^{\circ} \mathrm{C}$ until analysis. The other portion (200 mg) was also stored at $-80^{\circ} \mathrm{C}$ until analysis.

\section{Chemical analyses}

Analytical DM content of oven-dried samples was determined by drying at $135^{\circ} \mathrm{C}$ for $3 \mathrm{~h}$ (AOAC International, 1995; method 930.15), and organic matter $(\mathrm{OM})$ was estimated by the difference value between DM and crude ash measured by combustion at $550{ }^{\circ} \mathrm{C}$ for $5 \mathrm{~h}$. Content of neutral detergent fibre (NDF) was determined using the method of Van Soest et al. (1991) with heat-stable $\alpha$-amylase and sodium sulphite used in the procedure, whereas acid detergent fibre (ADF) was evaluated according to AOAC International (2000; method 973.18), and expressed inclusive of residual ash. Content of $\mathrm{N}$ in the samples was determined by the Kjeldahl method (AOAC International, 1995; method 976.05). Crude ether extract (EE) in the samples was determined by the Soxhlet method (AOAC International, 1995; method 954.02). Chromium content of faecal samples was determined by atomic absorption spectrophotometry (TAS-990, Beijing Purkinje General Instrument Co., Ltd., Beijing, China) as described by Williams et al. (1962).

Ruminal VFA was measured by gas chromatography (GC102AF; Shanghai Specialties Ltd., Shanghai, China) using a 2-m (4-mm diameter) fused PEG2000, Chromsob WAW DMCS column (GC102AF; Shanghai Specialties Ltd., Shanghai, China) with 2-ethylbutyric acid as the internal standard. Ruminal ammonia-N concentration was determined by a colorimetric spectrophotometer (UV2100, Shanghai Younike Instrument Co., Ltd., Shanghai, China). 
Table 2. Primers for Real-Time PCR assay

\begin{tabular}{|c|c|c|c|c|}
\hline Gene & $\begin{array}{l}\text { Primer sequence } \\
\text { (Fwd - forward, Rev - reversed) }\end{array}$ & $\begin{array}{l}\text { GenBank } \\
\text { accession no. }\end{array}$ & $\begin{array}{l}\text { Annealing } \\
\text { temperature, }^{\circ}\end{array}$ & $\begin{array}{l}\text { Product size, } \\
\text { bp }\end{array}$ \\
\hline $\mathrm{GH}$ & $\begin{array}{l}\text { Fwd-5'- TGTTTGCCAACGCTGTGCT -3' } \\
\text { Rev-5'- CCTGGGTGTTCTGGATGGAGTA -3' }\end{array}$ & NM_180996.1 & 61 & 120 \\
\hline INS & $\begin{array}{l}\text { Fwd-5'- CCTTCGTCAACCAGCATCTG -3' } \\
\text { Rev-5'- CTTGGGCGTGTAGAAGAAGC -3' }\end{array}$ & NM_001185126.1 & 59 & 89 \\
\hline IGF-1 & $\begin{array}{l}\text { Fwd-5'- ATCAGCAGTCTTCCAACCCAAT -3' } \\
\text { Rev-5'- TGAAGGCGAGCAAGCACAG -3' }\end{array}$ & NM_001077828.1 & 60 & 121 \\
\hline GHR & $\begin{array}{l}\text { Fwd-5'- GTTTGACAGAGATTCATGCCGAC -3' } \\
\text { Rev-5'- CAGTCTCAACGAGTACATCGGAAC -3' }\end{array}$ & NM_176608.1 & 60 & 179 \\
\hline INSR & $\begin{array}{l}\text { Fwd-5'- TTTGAGGACATGGAGAGCGT -3' } \\
\text { Rev-5'- GTTCATGTGGGTGTAGGGGA -3' }\end{array}$ & XM_005208817.4 & 59 & 135 \\
\hline IGF-1R & $\begin{array}{l}\text { Fwd-5'- CGGCTCAACCCAGGGAACTA -3' } \\
\text { Rev-5'- CCACTATCAACAGAACCGCAATG -3' }\end{array}$ & NM_001244612.1 & 60 & 163 \\
\hline mTOR & $\begin{array}{l}\text { Fwd-5'- CATCATTCGCATTCAGTCCATC -3' } \\
\text { Rev-5'- TCCTGCCGCAAGTCCTCAT -3' }\end{array}$ & XM_002694043.6 & 59 & 138 \\
\hline $4 E B P 1$ & $\begin{array}{l}\text { Fwd-5'- TTTGAGATGGACATTTAAAGGGC -3' } \\
\text { Rev-5'- CTTGCATAAGGCCTGGCTG -3' }\end{array}$ & NM_001077893.2 & 58 & 101 \\
\hline S6K & $\begin{array}{l}\text { Fwd-5'- CCAGCACGGCAAATCCGCAG -3' } \\
\text { Rev-5'- AAGCCTCCCCGCTCATCGTCA-3' }\end{array}$ & NM_205816.1 & 65 & 90 \\
\hline
\end{tabular}

4EBP1 - eukaryotic translation initiation factor 4E-binding protein 1; GH - growth hormone; GHR - growth hormone receptor; IGF-1 - insulin-like growth factor-1; IGF-1R - insulin-like growth factor-1 receptor; INS - insulin; INSR - insulin receptor; mTOR - mammalian target of rapamycin; $S 6 K$ - ribosomal protein S6 kinase

Serum contents of glucose, albumin, triglyceride, growth hormone releasing hormone (GHRH), GH, INS and IGF-1 were determined with the use of Konelab TM auto analyser (ThermoFisher Scientific - Oy, Vantaa, Finland) by using the corresponding enzyme-linked immunosorbent assay (ELISA) kit (Shanghai Du Ma Biology Science and Technology Co., Ltd, Shanghai, China).

\section{Extraction of RNA and quantitative real- time PCR}

Total RNA was extracted from the liver biopsies by using a Total RNA isolation kit (Invitrogen, Carlsbad, CA, USA) according to the manufacturer's protocol. The quality and concentration of the isolated RNA was determined by using a NanoDrop ND-1000 Spectrophotometer (NanoDrop Technologies, Rockland, DE, USA). The ratios of absorbance at 260 and $280 \mathrm{~nm}$ of all preparations were approximately 2.0. The integrity of RNA was checked by denaturing agarose gel electrophoresis and ethidium bromide staining. The iScriptTM cDNA Synthesis Kit (Bio-Rad Laboratories GmbH, Munich, Germany) was used to synthesize cDNA from 500 ng total RNA for each sample per $10 \mu \mathrm{l}$ sample reaction according to the manufacturer's instructions. Reaction conditions were $15 \mathrm{~min}$ at $37{ }^{\circ} \mathrm{C}$ and $5 \mathrm{~min}$ at $85^{\circ} \mathrm{C}$. Negative control reactions without reverse transcriptase, were performed on each sample to detect possible contamination of genomic DNA or environmental DNA (Kuzinski et al., 2011).

The mRNA abundance for $G H, G H R, I G F-1$, IGF-1 receptor (IGF-1R), INS, INS receptor (INSR), $m T O R, 4 E B P 1$ and $S 6 K$ were quantified by quantitative real-time PCR (qRT-PCR) using the iCycler and the iQ-SYBR green detection (Bio-Rad Laboratories, Hercules, CA, USA). The 16S rRNA sequences of all genes were searched on NCBI. Primer 3.0 software was used for on-line analysis, and the primers presented in Table 2 were designed. The primers were synthesized by Beijing Genomics Institute (BGI, Beijing, China). Subsequent qPCR was performed on a MxPro- Mx3000P multiplex quantitative PCR systems (Stratagene, La Jolla, CA, USA) at a minimum in triplicate. The reaction mixture $(20 \mu \mathrm{l})$ consisted of $2 \mu \mathrm{l}$ cDNA, $10 \mu \mathrm{l} \mathrm{SYBR}$ Premix Taq $^{\mathrm{TM}}$ II (TaKaRa Biotechnology Co., Ltd., Dalian, China), $0.8 \mu$ l PCR Forward Primer $(10 \mu \mathrm{M}), 0.8 \mu \mathrm{l}$ PCR Reverse Primer $(10 \mu \mathrm{M})$, $0.4 \mu 1$ ROX Reference Dye II, and $6.0 \mu 1 \mathrm{dH}_{2} \mathrm{O}$. The PCR was performed under the following cycle conditions: 1 cycle of $95^{\circ} \mathrm{C}$ for $20 \mathrm{~s}, 45$ cycles of $95^{\circ} \mathrm{C}$ for $20 \mathrm{~s}$, and annealing temperature for $30 \mathrm{~s}$, and $62{ }^{\circ} \mathrm{C}$ for $20 \mathrm{~s}$, followed by a melting curve analysis (Denman and McSweeney, 2006). Fluorescence detection was performed at the end of each denaturation and extension step. Relative quantity of genes was done as a proportion of $18 \mathrm{~S}$ rRNA according to the equation: 
relative quantification $=2^{-\Delta \Delta \mathrm{Ct}}$,

where: $\Delta \Delta \mathrm{Ct}=\Delta \mathrm{Ct}$ (test samples) $-\Delta \mathrm{Ct}$ (calibrator samples); $\Delta \mathrm{Ct}($ test samples $)=\mathrm{Ct}($ target genes in tests) - $\mathrm{Ct}$ (reference genes in tests); $\Delta \mathrm{Ct}$ (calibrator samples $)=\mathrm{Ct}$ (target genes in calibrator) $\mathrm{Ct}$ (reference genes in calibrator).

\section{Statistical analyses}

Feed conversion ratio (FCR) was calculated as daily DM intake divided by ADG for each calf. Data were analysed using the mixed model procedure of SAS software (SAS, 2002). Analysis of variance (ANOVA) was used to examine the effect of treatment on growth performance, ruminal fermentation, nutrient digestibility, mRNA abundance for $G H, G H R, I G F-1, I G F-1 R, I N S, I N S R$, mTOR, $4 E B P 1$ and $S 6 K$ and blood metabolites. Linear and quadratic orthogonal contrasts were tested using the CONTRAST statement of SAS software with coefficients estimated based on the BCVFA application rates. The main effects of treatment were compared using the Duncan's test. Effects of the factors were declared significant at $P<0.05$ unless otherwise noted and trends are discussed at $P<0.1$.

\section{Results}

\section{Dry matter intake, average daily gain and feed conversion ratio}

Dietary BCVFA addition linearly increased $(P<0.05)$ DM intake in calves from 61 to 90 day of age and from 121 to 150 day of age (Table 3). The overall DM intake linearly $(P=0.038)$ increased and was higher for HBC and MBC groups than for control one. At 60 day of age no difference was observed for BW in all groups, but BW for calves at 90,120 and 150 day of age increased $(P<0.05)$ linearly and were higher for HBC and MBC groups in comparison to control group. Higher $(P<0.05)$ ADG was observed in HBC and MBC groups during the trial. Dietary BCVFA addition did not affect FCR of calves between 61 and 90 day of age, but decreased $(P<0.05)$ FCR in calves between 91 and 120 day of age and 121 and 150 day of age. As a result, the overall FCR decreased $(P=0.016)$ linearly with increasing BCVFA addition and was lower for HBC and MBC groups than for control one.

Table 3. Effects of branched-chain volatile fatty acids (BCVFA) supplementation on dry matter intake, average daily gain and feed conversion ratio in post-weaned dairy calves

\begin{tabular}{|c|c|c|c|c|c|c|c|c|}
\hline \multirow{3}{*}{ Indices } & \multicolumn{4}{|c|}{ Treatments $^{1}$} & \multirow{3}{*}{ SEM } & \multicolumn{3}{|l|}{$P$-value } \\
\hline & \multirow[t]{2}{*}{ control } & \multirow[t]{2}{*}{ LBC } & \multirow[t]{2}{*}{ MBC } & \multirow[t]{2}{*}{$\mathrm{HBC}$} & & \multirow[t]{2}{*}{ treatment } & \multicolumn{2}{|c|}{ contrast } \\
\hline & & & & & & & linear & quadratic \\
\hline \multicolumn{9}{|l|}{ Dry matter intake, $\mathrm{kg} / \mathrm{day}$} \\
\hline $61-90$ days of age & $3.25^{b}$ & $3.76^{\mathrm{ab}}$ & $3.89^{a}$ & $4.01^{\mathrm{a}}$ & 0.115 & 0.029 & 0.035 & 0.443 \\
\hline $91-120$ days of age & 4.25 & 4.21 & 4.32 & 4.26 & 0.146 & 0.185 & 0.384 & 0.142 \\
\hline $121-150$ days of age & $5.93^{b}$ & $5.93^{\mathrm{ab}}$ & $6.19^{a}$ & $6.14^{\mathrm{a}}$ & 0.201 & 0.031 & 0.042 & 0.157 \\
\hline overall & $4.48^{b}$ & $4.62^{\mathrm{ab}}$ & $4.79^{a}$ & $4.80^{\mathrm{a}}$ & 0.198 & 0.043 & 0.038 & 0.805 \\
\hline \multicolumn{9}{|l|}{ Body weight, kg } \\
\hline 60 day of age & 69.5 & 68.9 & 69.2 & 68.4 & 1.68 & 0.712 & 0.895 & 0.734 \\
\hline 90 day of age & $104^{b}$ & $106^{\mathrm{ab}}$ & $108^{a}$ & $108^{a}$ & 2.32 & 0.033 & 0.026 & 0.424 \\
\hline 120 day of age & $146^{b}$ & $149^{\mathrm{ab}}$ & $155^{\mathrm{a}}$ & $155^{\mathrm{a}}$ & 6.05 & 0.010 & 0.041 & 0.378 \\
\hline 150 day of age & $188^{b}$ & $195^{\mathrm{ab}}$ & $205^{\mathrm{a}}$ & $206^{\mathrm{a}}$ & 5.2 & 0.027 & 0.045 & 0.693 \\
\hline \multicolumn{9}{|l|}{ Average daily gain, kg/day } \\
\hline $61-90$ days of age & $1.16^{b}$ & $1.24^{\mathrm{ab}}$ & $1.29^{\mathrm{a}}$ & $1.31^{\mathrm{a}}$ & 0.054 & 0.047 & 0.046 & 0.523 \\
\hline $91-120$ days of age & $1.38^{b}$ & $1.44^{\mathrm{ab}}$ & $1.56^{\mathrm{a}}$ & $1.58^{\mathrm{a}}$ & 0.098 & 0.039 & 0.040 & 0.465 \\
\hline $121-150$ days of age & $1.41^{\mathrm{b}}$ & $1.53^{\mathrm{ab}}$ & $1.68^{\mathrm{a}}$ & $1.70^{\mathrm{a}}$ & 0.086 & 0.033 & 0.027 & 0.181 \\
\hline overall & $1.32^{b}$ & $1.40^{\mathrm{ab}}$ & $1.51^{\mathrm{a}}$ & $1.53^{\mathrm{a}}$ & 0.093 & 0.036 & 0.029 & 0.547 \\
\hline \multicolumn{9}{|l|}{$\mathrm{FCR}^{2}, \mathrm{~kg} / \mathrm{kg}$} \\
\hline $61-90$ days of age & 2.80 & 3.03 & 3.02 & 3.06 & 0.124 & 0.087 & 0.316 & 0.475 \\
\hline $91-120$ days of age & $3.08^{a}$ & $2.93^{\mathrm{ab}}$ & $2.77^{\mathrm{b}}$ & $2.70^{b}$ & 0.137 & 0.032 & 0.034 & 0.521 \\
\hline $121-150$ days of age & $4.21^{\mathrm{a}}$ & $3.87^{\mathrm{ab}}$ & $3.68^{b}$ & $3.61^{\mathrm{b}}$ & 0.156 & 0.043 & 0.026 & 0.397 \\
\hline overall & $3.36^{\mathrm{a}}$ & $3.28^{\mathrm{ab}}$ & $3.17^{\mathrm{b}}$ & $3.12^{b}$ & 0.134 & 0.021 & 0.016 & 0.438 \\
\hline
\end{tabular}

1 treatments: control, low-BCVFA (LBC), medium-BCVFA (MBC) and high-BCVFA (HBC) with 0, 1.5, 3.0 and $4.5 \mathrm{~g}$ BCVFA per kg dietary DM, respectively; ${ }^{2} \mathrm{FCR}$ - feed conversion ratio; a,b,c - means with different superscripts in each row differ significantly $(P<0.05)$ 


\section{Ruminal fermentation and nutrient digestibility}

Ruminal $\mathrm{pH}$ decreased linearly $(P<0.05$; Table 4) with increasing dietary BCVFA addition, and was lower in $\mathrm{HBC}$ and $\mathrm{MBC}$ groups than for control.
Higher $(P<0.05)$ ruminal total VFA concentration was observed in animals from $\mathrm{HBC}$ and $\mathrm{MBC}$ groups than for control. In comparison to control group, the increase $(P<0.05)$ in acetate molar proportion and decrease $(P<0.05)$ in propionate molar proportion

Table 4. Effects of branched-chain volatile fatty acids (BCVFA) supplementation on ruminal fermentation in post-weaned dairy calves

\begin{tabular}{|c|c|c|c|c|c|c|c|c|}
\hline \multirow{3}{*}{ Indices } & \multicolumn{4}{|c|}{ Treatments $^{1}$} & \multirow{3}{*}{ SEM } & \multicolumn{3}{|l|}{$P$-value } \\
\hline & \multirow[t]{2}{*}{ control } & \multirow[t]{2}{*}{ LBC } & \multirow[t]{2}{*}{ MBC } & \multirow[t]{2}{*}{$\mathrm{HBC}$} & & \multirow[t]{2}{*}{ treatment } & \multicolumn{2}{|c|}{ contrast } \\
\hline & & & & & & & linear & quadratic \\
\hline \multicolumn{9}{|l|}{$\mathrm{pH}$} \\
\hline 105 day of age & $6.73^{a}$ & $6.61^{\mathrm{ab}}$ & $6.42^{b}$ & $6.35^{\mathrm{b}}$ & 0.062 & 0.038 & 0.013 & 0.423 \\
\hline 150 day of age & $6.64^{a}$ & $6.52^{\mathrm{ab}}$ & $6.33^{b}$ & $6.29^{b}$ & 0.059 & 0.044 & 0.010 & 0.365 \\
\hline \multicolumn{9}{|l|}{ Total VFA, mM } \\
\hline 105 day of age & $88.6^{b}$ & $90.4^{\mathrm{ab}}$ & $100.5^{\mathrm{a}}$ & $101.9^{a}$ & 2.78 & 0.015 & 0.023 & 0.538 \\
\hline 150 day of age & $91.5^{b}$ & $93.8^{\mathrm{ab}}$ & $103.4^{\mathrm{a}}$ & $105.1^{\mathrm{a}}$ & 2.51 & 0.001 & 0.001 & 0.467 \\
\hline \multicolumn{9}{|l|}{$\begin{array}{l}\text { VFA, mol/100 mol } \\
\text { acetate (A) }\end{array}$} \\
\hline 105 day of age & $59.1^{\mathrm{b}}$ & $59.6^{\mathrm{ab}}$ & $60.9^{a}$ & $60.3^{\mathrm{a}}$ & 1.29 & 0.022 & 0.016 & 0.376 \\
\hline $\begin{array}{l}150 \text { day of age } \\
\text { propionate }(P)\end{array}$ & $60.3^{b}$ & $60.8^{\mathrm{ab}}$ & $62.1^{\mathrm{a}}$ & $61.5^{\mathrm{a}}$ & 1.13 & 0.001 & 0.001 & 0.538 \\
\hline 105 day of age & $28.6^{a}$ & $26.8^{\mathrm{ab}}$ & $25.0^{\mathrm{b}}$ & $24.8^{\mathrm{b}}$ & 2.11 & 0.021 & 0.019 & 0.549 \\
\hline 150 day of age & $25.7^{\mathrm{a}}$ & $24.0^{\mathrm{ab}}$ & $22.2^{b}$ & $21.9^{b}$ & 1.82 & 0.018 & 0.027 & 0.737 \\
\hline \multicolumn{9}{|l|}{ butyrate } \\
\hline 105 day of age & $8.89^{b}$ & $9.71^{\mathrm{ab}}$ & $10.3^{a}$ & $10.9^{\mathrm{a}}$ & 0.31 & 0.037 & 0.023 & 0.426 \\
\hline \multicolumn{8}{|l|}{ isobutyrate } & 0.398 \\
\hline 105 day of age & $1.51^{b}$ & $1.59^{a b}$ & $1.70^{\mathrm{a}}$ & $1.67^{\mathrm{a}}$ & 0.031 & 0.019 & 0.028 & 0.135 \\
\hline $\begin{array}{l}150 \text { day of age } \\
\text { isovalerate }\end{array}$ & $1.64^{b}$ & $1.71^{\mathrm{ab}}$ & $1.84^{\mathrm{a}}$ & $1.80^{\mathrm{a}}$ & 0.031 & 0.013 & 0.030 & 0.223 \\
\hline 105 day of age & $0.89^{b}$ & $1.25^{\mathrm{ab}}$ & $1.32^{\mathrm{a}}$ & $1.38^{a}$ & 0.071 & 0.013 & 0.025 & 0.492 \\
\hline $\begin{array}{l}150 \text { day of age } \\
\text { valerate }\end{array}$ & $1.01^{b}$ & $1.38^{\mathrm{ab}}$ & $1.42^{\mathrm{a}}$ & $1.51^{\mathrm{a}}$ & 0.064 & 0.008 & 0.002 & 0.601 \\
\hline 105 day of age & 1.04 & 1.06 & 0.87 & 1.02 & 0.029 & 0.624 & 0.535 & 0.581 \\
\hline 150 day of age & 1.19 & 1.19 & 1.01 & 1.13 & 0.034 & 0.528 & 0.489 & 0.440 \\
\hline \multicolumn{9}{|l|}{$A: P$} \\
\hline 105 day of age & $2.07^{\mathrm{b}}$ & $2.22^{\mathrm{ab}}$ & $2.44^{a}$ & $2.43^{a}$ & 0.084 & 0.011 & 0.025 & 0.175 \\
\hline 150 day of age & $2.35^{b}$ & $2.53^{\mathrm{ab}}$ & $2.80^{\mathrm{a}}$ & $2.81^{\mathrm{a}}$ & 0.096 & 0.003 & 0.001 & 0.117 \\
\hline \multicolumn{9}{|c|}{ Ammonia $\mathrm{N}, \mathrm{mg} / 100 \mathrm{ml}$} \\
\hline 105 day of age & $9.38^{\mathrm{a}}$ & $9.24^{\mathrm{ab}}$ & $8.32^{b}$ & $8.25^{\mathrm{b}}$ & 0.83 & 0.021 & 0.026 & 0.634 \\
\hline 150 day of age & $10.42^{\mathrm{a}}$ & $10.01^{\mathrm{ab}}$ & $9.26^{b}$ & $8.98^{b}$ & 0.79 & 0.012 & 0.037 & 0.732 \\
\hline
\end{tabular}

${ }^{1}$ treatments: control, low-BCVFA (LBC), medium-BCVFA (MBC) and high-BCVFA (HBC) with 0, 1.5, 3.0 and $4.5 \mathrm{~g}$ BCVFA per kg dietary DM, respectively; abc - means with different superscripts in each row are significantly different $(P<0.05)$

Table 5. Effects of branched-chain volatile fatty acids (BCVFA) supplementation on apparent total tract nutrient digestibility in post-weaned dairy calves

\begin{tabular}{|c|c|c|c|c|c|c|c|c|}
\hline \multirow{3}{*}{ Digestibility } & \multicolumn{4}{|c|}{ Treatments $^{1}$} & \multirow{3}{*}{ SEM } & \multicolumn{3}{|l|}{$P$-value } \\
\hline & \multirow[t]{2}{*}{ control } & \multirow[t]{2}{*}{ LBC } & \multirow[t]{2}{*}{ MBC } & \multirow[t]{2}{*}{$\mathrm{HBC}$} & & \multirow[t]{2}{*}{ treatment } & \multicolumn{2}{|c|}{ contrast } \\
\hline & & & & & & & linear & quadratic \\
\hline Dry matter & $0.84^{\mathrm{b}}$ & $0.87^{a b}$ & $0.90^{\mathrm{a}}$ & $0.89^{\mathrm{a}}$ & 0.005 & 0.043 & 0.025 & 0.201 \\
\hline Organic matter & $0.82^{b}$ & $0.85^{\mathrm{ab}}$ & $0.88^{a}$ & $0.89^{\mathrm{a}}$ & 0.006 & 0.028 & 0.019 & 0.398 \\
\hline Crude protein & $0.78^{b}$ & $0.83^{\mathrm{ab}}$ & $0.85^{\mathrm{a}}$ & $0.86^{\mathrm{a}}$ & 0.007 & 0.034 & 0.027 & 0.422 \\
\hline Ether extract & $0.86^{\mathrm{b}}$ & $0.91^{\mathrm{ab}}$ & $0.94^{a}$ & $0.95^{\mathrm{a}}$ & 0.006 & 0.040 & 0.033 & 0.467 \\
\hline Neutral detergent fibre & $0.54^{\mathrm{b}}$ & $0.60^{\mathrm{ab}}$ & $0.61^{a}$ & $0.62^{\mathrm{a}}$ & 0.007 & 0.038 & 0.027 & 0.398 \\
\hline Acid detergent fibre & $0.50^{\mathrm{b}}$ & $0.53^{\mathrm{ab}}$ & $0.55^{a}$ & $0.56^{a}$ & 0.005 & 0.029 & 0.021 & 0.376 \\
\hline
\end{tabular}

1 treatments: control, low-BCVFA (LBC), medium-BCVFA (MBC) and high-BCVFA (HBC) with 0, 1.5, 3.0 and $4.5 \mathrm{~g}$ BCVFA per kg dietary DM, respectively; abc - means with different superscripts in each row are significantly different $(P<0.05)$ 
resulted in higher $(P<0.05)$ acetate:propionate ratio in HBC and MBC groups. Dietary addition of 3.0 and $4.5 \mathrm{~g} / \mathrm{kg}$ DM of BCVFA increased $(P<0.05)$ molar proportions of butyrate, isobutyrate and isovalerate, but did not affect valerate molar proportion. Ammonia-N content decreased $(P<0.05)$ linearly with increasing BCVFA addition and was lower in $\mathrm{HBC}$ and $\mathrm{MBC}$ groups than in control one. Higher $(P<0.05$; Table 5) digestibilities of DM, OM, crude protein (CP), EE, NDF and ADF were observed in $\mathrm{HBC}$ and $\mathrm{MBC}$ groups in comparison to control one.

\section{Blood metabolites and hormone concentration}

Dietary BCVFA addition increased $(P<0.05)$ blood glucose content, but did not affect blood triglyceride concentration (Table 6). Higher $(P<0.05)$ blood concentrations of albumin, GHRH, GH, INS

Table 6. Effects of branched-chain volatile fatty acids (BCVFA) supplementation on blood metabolites and hormones in post-weaned dairy calves

\begin{tabular}{|c|c|c|c|c|c|c|c|c|}
\hline \multirow{3}{*}{ Indices $^{2}$} & \multicolumn{4}{|c|}{ Treatment } & \multirow{3}{*}{ SEM } & \multicolumn{3}{|l|}{$P$-value } \\
\hline & \multirow[t]{2}{*}{ control } & \multirow[t]{2}{*}{ LBC } & \multirow[t]{2}{*}{ MBC } & \multirow[t]{2}{*}{$\mathrm{HBC}$} & & \multirow[t]{2}{*}{ treatment } & \multicolumn{2}{|c|}{ contrast } \\
\hline & & & & & & & linear & quadratic \\
\hline \multicolumn{9}{|l|}{ Glucose, $\mathrm{mmol} / / \mathrm{l}$} \\
\hline 106 day of age & $3.11^{\mathrm{b}}$ & $3.43^{\mathrm{a}}$ & $3.72^{\mathrm{a}}$ & $3.71^{\mathrm{a}}$ & 0.351 & 0.036 & 0.028 & 0.215 \\
\hline 151 day of age & $2.99^{b}$ & $3.32^{\mathrm{a}}$ & $3.64^{a}$ & $3.60^{\mathrm{a}}$ & 0.335 & 0.042 & 0.033 & 0.182 \\
\hline \multicolumn{9}{|l|}{ Triglyceride, mmol/l } \\
\hline 106 day of age & 0.31 & 0.33 & 0.34 & 0.32 & 0.031 & 0.253 & 0.325 & 0.201 \\
\hline 151 day of age & 0.32 & 0.35 & 0.33 & 0.35 & 0.022 & 0.147 & 0.138 & 0.614 \\
\hline \multicolumn{9}{|l|}{ Albumin, g/l } \\
\hline 106 day of age & $35.4^{b}$ & $36.9^{a b}$ & $37.5^{\mathrm{a}}$ & $38.1^{\mathrm{a}}$ & 1.48 & 0.027 & 0.029 & 0.428 \\
\hline 151 day of age & $34.8^{b}$ & $35.3^{\mathrm{ab}}$ & $36.7^{\mathrm{a}}$ & $36.9^{a}$ & 1.48 & 0.035 & 0.041 & 0.557 \\
\hline \multicolumn{9}{|l|}{ GHRH, ng/ml } \\
\hline 106 day of age & $9.37^{b}$ & $11.3^{\mathrm{ab}}$ & $12.2^{\mathrm{a}}$ & $12.4^{\mathrm{a}}$ & 0.86 & 0.017 & 0.021 & 0.702 \\
\hline 151 day of age & $10.2^{b}$ & $12.4^{\mathrm{ab}}$ & $12.8^{\mathrm{a}}$ & $12.9^{a}$ & 0.92 & 0.029 & 0.025 & 0.613 \\
\hline \multicolumn{9}{|c|}{$\mathrm{GH}, \mathrm{ng} / \mathrm{ml}$} \\
\hline 106 day of age & $3.81^{\mathrm{b}}$ & $4.35^{\mathrm{ab}}$ & $4.86^{\mathrm{a}}$ & $4.91^{\mathrm{a}}$ & 0.814 & 0.023 & 0.027 & 0.496 \\
\hline 151 day of age & $3.72^{b}$ & $4.23^{a b}$ & $4.77^{\mathrm{a}}$ & $4.80^{\mathrm{a}}$ & 0.732 & 0.035 & 0.031 & 0.585 \\
\hline \multicolumn{9}{|l|}{ INS, ng/ml } \\
\hline 106 day of age & $4.82^{b}$ & $5.06^{\mathrm{ab}}$ & $5.55^{\mathrm{a}}$ & $5.87^{a}$ & 0.163 & 0.021 & 0.032 & 0.571 \\
\hline 151 day of age & $4.71^{\mathrm{b}}$ & $4.98^{\mathrm{ab}}$ & $5.36^{\mathrm{a}}$ & $5.82^{\mathrm{a}}$ & 0.155 & 0.015 & 0.027 & 0.612 \\
\hline \multicolumn{9}{|l|}{ IGF-1, ng/ml } \\
\hline 106 day of age & $37.4^{b}$ & $39.1^{\mathrm{ab}}$ & $40.3^{a}$ & $41.5^{\mathrm{a}}$ & 3.02 & 0.038 & 0.026 & 0.498 \\
\hline 151 day of age & $35.8^{b}$ & $37.2^{\mathrm{ab}}$ & $38.8^{\mathrm{a}}$ & $39.0^{\mathrm{a}}$ & 2.92 & 0.049 & 0.038 & 0.543 \\
\hline
\end{tabular}

1 treatments: control, low-BCVFA (LBC), medium-BCVFA (MBC) and high-BCVFA (HBC) with 0, 1.5, 3.0 and $4.5 \mathrm{~g}$ BCVFA per kg dietary $\mathrm{DM}$, respectively; ${ }^{2} \mathrm{GHRH}$ - growth hormone releasing hormone, GH - growth hormone, INS - insulin, IGF-1 - insulin-like growth factor-1; abc - means with different superscripts in each row are significantly different $(P<0.05)$

Table 7. Effects of branched-chain volatile fatty acids (BCVFA) supplementation on hepatic mRNA expression of genes in post-weaned dairy calves (proportion of $18 \mathrm{~S}$ rRNA)

\begin{tabular}{|c|c|c|c|c|c|c|c|c|}
\hline \multirow{3}{*}{ Gene ${ }^{1}$} & \multicolumn{4}{|c|}{ Treatment } & \multirow{3}{*}{ SEM } & \multicolumn{3}{|l|}{$P$-value } \\
\hline & \multirow[t]{2}{*}{ control } & \multirow[t]{2}{*}{ LBC } & \multirow[t]{2}{*}{ MBC } & \multirow[t]{2}{*}{$\mathrm{HBC}$} & & \multirow[t]{2}{*}{ treatment } & \multicolumn{2}{|c|}{ contrast } \\
\hline & & & & & & & linear & quadratic \\
\hline $\mathrm{GH}$ & $0.28^{b}$ & $0.32^{\mathrm{ab}}$ & $0.40^{\mathrm{a}}$ & $0.43^{a}$ & 0.081 & 0.031 & 0.018 & 0.612 \\
\hline INS & $0.10^{b}$ & $0.13^{\mathrm{ab}}$ & $0.16^{a}$ & $0.18^{a}$ & 0.065 & 0.039 & 0.044 & 0.219 \\
\hline IGF-1 & $0.63^{b}$ & $0.74^{\mathrm{ab}}$ & $0.87^{a}$ & $0.89^{a}$ & 0.134 & 0.042 & 0.039 & 0.435 \\
\hline GHR & $0.38^{b}$ & $0.41^{\mathrm{ab}}$ & $0.48^{\mathrm{a}}$ & $0.49^{a}$ & 0.073 & 0.013 & 0.021 & 0.196 \\
\hline INSR & $0.06^{b}$ & $0.07^{\mathrm{ab}}$ & $0.08^{a}$ & $0.08^{a}$ & 0.012 & 0.017 & 0.028 & 0.337 \\
\hline IGF-1R & $0.47^{b}$ & $0.54^{\mathrm{ab}}$ & $0.67^{a}$ & $0.69^{a}$ & 0.073 & 0.011 & 0.035 & 0.505 \\
\hline mTOR & $0.56^{b}$ & $0.61^{\mathrm{ab}}$ & $0.73^{a}$ & $0.75^{a}$ & 0.125 & 0.023 & 0.011 & 0.756 \\
\hline $4 E B P 1$ & $0.61^{b}$ & $0.69^{a b}$ & $0.83^{a}$ & $0.84^{a}$ & 0.142 & 0.035 & 0.026 & 0.398 \\
\hline S6K & $0.66^{b}$ & $0.73^{\mathrm{ab}}$ & $0.89^{a}$ & $0.91^{\mathrm{a}}$ & 0.220 & 0.028 & 0.015 & 0.474 \\
\hline
\end{tabular}

${ }_{1}^{1} 4 E B P 1$ - eukaryotic translation initiation factor 4E-binding protein 1, GH - growth hormone, GHR - growth hormone receptor, IGF-1 - insulin-like growth factor-1, IGF-1R - insulin-like growth factor-1 receptor, INS - insulin, INSR - insulin receptor, $m$ TOR - mammalian target of rapamycin, S6K - ribosomal protein S6 kinase; ${ }^{2}$ treatments: control, low-BCVFA (LBC), medium-BCVFA (MBC) and high-BCVFA (HBC) with 0 , 1.5, 3.0 and 4.5 g BCVFA per kg dietary DM, respectively; ${ }^{\text {abc }}$ - means with different superscripts in each row are significantly different $(P<0.05)$ 
and IGF-1 were observed for $\mathrm{HBC}$ and MBC than for control.

\section{Hepatic gene expression}

Dietary addition of 3.0 (MBC) and 4.5 (HBC) $\mathrm{g} / \mathrm{kg}$ DM of BCVFA increased hepatic mRNA abundance of $G H, I N S, I G F-1, G H R$, INSR and $I G F-1 R$ in calves (Table 7). Hepatic mRNAabundance of $m T O R$ and its downstream genes, $4 E B P 1$ and $S 6 K$, increased linearly $(P<0.05)$ with increasing BCVFA addition and were higher in $\mathrm{MBC}$ and $\mathrm{HBC}$ groups than in control one.

\section{Discussion}

The positive impact of BCVFA addition on DM intake was associated with the increase in digestibility of NDF and ADF, which relieved ruminal distension of calves (Allen, 2000). The positive response of ADG was attributed to the increase in DM intake, ruminal total VFA concentration and nutrient digestibility, indicating that nutrient utilization was improved, as evidenced by the observed decrease in FCR with dietary BCVFA addition. Additionally, Wang et al. (2017) found that dietary BCVFA addition stimulated the rumen development, and then improved the ability of nutrient digestion and absorption in calves. Moreover, BCVFA, as the precursor of ketogenesis and gluconeogenesis, could promote the growth of calves by regulating the intermediary metabolism (Andries et al., 1987). Similarly, in previous studies it was found that DM intake and ADG increased, and FCR decreased with single BCVFA (isobutyrate or 2-methylbutyrate) supplementation in calves (Liu et al., 2016; Wang et al., 2017).

The positive impacts of BCVFA addition on digestibility of DM, OM, CP, EE, NDF and ADF were in accordance with the findings of Liu et al. (2008; 2009), in which nutrient digestibility of steers increased after isobutyrate or isovalerate supplementation. The increase in digestibility of NDF and $\mathrm{ADF}$ were consistent with the increased ruminal molar proportions of acetate and butyrate, indicating that cellulolytic bacteria growth and enzyme activity were stimulated by BCVFA supplementation. Ruminal BCVFA derive from the degradation of dietary protein, and are utilized by microbes to synthesis their branched-chain amino acids, higher branched-chain fatty acids and aldehydes (Cummins and Papas, 1985). Dietary BCVFA supplementation reduced protein degradation in the rumen (Liu et al., 2014; Wang et al., 2015), and spared feed amino acids and energy for microbial growth. Previous studies indicated that the relative abundance of ruminal primary fibrolytic bacteria, Ruminococcus (R.) albus, R. flavefaciens, Butyrivibrio fibrisolvens and Fibrobacter succinogenes, as well as activities of caboxymethylcellulase, cellobiase, xylanase and pectinase increased with isovalerate or isobutyrate supplementation in steers (Liu et al., 2014; Wang et al., 2015).

Ruminal pH ranged from 6.29 to 6.64 and was optimum for microbial growth and nutrient degradation (Russell and Wilson, 1996). The decrease in ruminal $\mathrm{pH}$ was consistent with the observed increase in total VFA concentration (Maekawa et al., 2002). The response of total VFA concentration was associated with the increased DM intake, and was also due to a positive impact of BCVFA on microbial growth and enzyme activity, as observed in other studies (Liu et al., 2014; Wang et al., 2015). The results supported the increased nutrient digestibility with BCVFA addition. The increase in acetate:propionate ratio resulted from the increase in acetate molar proportion and concomitant decrease in propionate molar proportion, indicating that ruminal fermentation pattern was altered to more acetate production following BCVFA supplementation. In the current study, although propionate molar proportion decreased due to BCVFA supplementation, propionate concentration was similar among treatments. The results suggested that the growth of propionate producing bacteria was not affected by BCVFA supplementation. Our results were in line with the results of Wang et al. (2015) who found that the relative abundance of ruminal amylolytic bacteria and amylase activity were not affected by isobutyrate supplementation in steers. Similarly, previous studies found that total VFA concentration and acetate molar proportion increased, but propionate molar proportion was unaltered with BCVFA supplementation in steers (Liu et al., 2008; 2009). The unchanged relative abundance of proteolytic bacteria, and a decreased protease activity and CP degradability were observed after BCVFA addition (Liu et al., 2014; Wang et al., 2015). The increase in molar proportions of isobutyrate and isovalerate were attributed to an exogenous BCVFA addition. Ruminal ammonia-N derives from feed protein degradation and is used by microorganisms to synthesize their protein (Russell et al., 1992). The decrease in ammonia-N concentration indicated that microbial protein synthesis was enhanced, as evidenced by previous studies, in which an increased urinary purine derivatives excretion was observed with BCVFA 
supplementation (Liu et al., 2008; 2009). This result explained the positive impacts of BCVFA addition on CP digestibility and ADG in calves (NRC, 2001).

The higher blood glucose level was consistent with the increase in blood concentration of INS, and was associated with an increased DM intake following BCVFA supplementation. Smith et al. (2002) observed that plasma glucose increased when nutrient intake increased in calves. Additionally, dietary supplemented BCVFA can be used as a precursor for gluconeogenesis (Andries et al., 1987). Similarly, Wang et al. (2017) found an increased blood glucose level in calves supplemented with isobutyrate. Blood albumin concentration can reflect feed protein availability (Lohakare et al., 2006). The increase in albumin was related to the increased CP digestibility and microbial protein synthesis, indicating that feed protein utilization was improved following BCVFA supplementation. The positive response of blood GHRH, GH, INS and IGF-1 were associated with the increase in DM intake and ruminal total VFA concentration with increasing BCVFA addition. In the literature it is demonstrated that plasma concentrations of GH, INS and IGF-1 were positively influenced by the increased nutrient intake or ruminal VFA concentration (Smith et al., 2002; Zhao and Sun, 2010). In our previous studies we have indicated that plasma GH and IGF-1 increased following 2-methylbutyrate or isobutyrate supplementation in post-weaned calves (Liu et al., 2016; Wang et al., 2017).

The positive response of hepatic mRNA abundance for $G H, I N S, I G F-1, G H R, I N S R$ and $I G F-1 R$ was consistent with the increase in blood GHRH, GH, INS and IGF-1, and was also associated with the increase in DM intake and ruminal total VFA concentration following BCVFA supplementation. The binding of $G H$ and $G H R$ in the liver promotes IGF-1 secretion and protein retention (Breier, 1999). Smith et al. (2002) observed that hepatic mRNA expression for $G H R$ and IGF-1 increased when nutrient intake was enhanced in calves. Zhao and Sun (2010) reported that hepatic IGF-1 content increased with increasing ruminal VFA infusion. It was shown that INS, GH and IGF-1 activate mTOR through binding with their own receptors, INSR, GHR and IGF-1R (Lee et al., 2010; Pivonello et al., 2016). The activation of mTOR leads to the phosphorylation of 4EBP1 and $\mathrm{S} 6 \mathrm{~K}$, and then stimulates protein synthesis and animal growth (Davis et al., 2000; Pivonello et al., 2016). Therefore, the observed increase in hepatic mRNA abundance for $m T O R, 4 E B P-1$ and $S 6 K$ was consistent with the increased abundance of $G H, I N S$,
$I G F-1, G H R, I N S R$ and IGF-1R, indicating that hepatic protein synthesis might be promoted by BCVFA supplementation in calves.

\section{Conclusions}

The increased average daily gain (ADG) was observed due to an increase in dry matter intake, ruminal total volatile fatty acids (VFA) concentration and nutrient digestibility with branched-chain volatile fatty acids (BCVFA) addition. The observed higher ADG was accompanied with an upregulated hepatic $m T O R, 4 E B P 1$ and $S 6 K$ expression, and this might be associated with the positive impact of dietary BCVFA addition on the secretion of growth hormone, insulin and insulin-like growth factor-1 as well as hepatic expression of $G H, I N S$, $I G F-1, G H R, I N S R$ and $I G F-1 R$. The optimum supplementary dose of BCVFA was $3.0 \mathrm{~g}$ per $\mathrm{kg} \mathrm{DM}$ for calves under the current experimental conditions.

\section{Acknowledgements}

This work was supported by a grant from Natural Science Funding projects of National Natural Science Fundation of China (31272471). The authors thank the staff of Shanxi Agriculture University beef unit for care of the animals.

\section{References}

Allen M.S., 2000. Effects of diet on short-term regulation of feed intake by lactating dairy cattle. J. Dairy Sci. 83, 1598-1624, https:// doi.org/10.3168/jds.S0022-0302(00)75030-2

Andries J.I., Buysse F.X., De Brabander D.L., Cottyn B.G., 1987. Isoacids in ruminant nutrition: their role in ruminal and intermediary metabolism and possible influences on performances - a review. Anim. Feed Sci. Technol. 18, 169-180, https://doi.org/10.1016/0377-8401(87)90069-1

AOAC International, 1995. Official Methods of Analysis of AOAC International. $16^{\text {th }}$ Edition. Arlington, VA (USA)

AOAC International, 2000. Official Methods of Analysis of AOAC International. $17^{\text {th }}$ Edition. Gaithersburg, MD (USA)

Breier B.H., 1999. Regulation of protein and energy metabolism by the somatotropic axis. Domest. Anim. Endocrinol. 17, 209-218, https://doi.org/10.1016/S0739-7240(99)00038-7

Cummins K.A., Papas A.H., 1985. Effect of isocarbon-4 and isocarbon-5 volatile fatty acids on microbial protein synthesis and dry matter digestibility in vitro. J. Dairy Sci. 68, 2588-2595, https://doi. org/10.3168/jds.S0022-0302(85)81141-3

Davis T.A., Nguyen H.V., Suryawan A., Bush J.A., Jefferson L.S., Kimball S.R., 2000. Developmental changes in the feedinginduced stimulation of translation initiation in muscle of neonatal pigs. Am. J. Physiol. Endocrinol. Metab. 279, E1226E1234, https://doi.org/10.1152/ajpendo.2000.279.6.E1226 
Denman S.E., McSweeney C.S., 2006. Development of a realtime PCR assay for monitoring anaerobic fungal and cellulolytic bacterial populations within the rumen. FEMS Microbiol. Ecol. 58, 572-582, https://doi.org/10.1111/j.15746941.2006.00190.x

Ferret A., Plaixats J., Caja G., Gasa J., Prió P., 1999. Using markers to estimate apparent dry matter digestibility, faecal output and dry matter intake in dairy ewes fed Italian ryegrass hay or alfalfa hay. Small Ruminant Res. 33, 145-152, https://doi. org/10.1016/S0921-4488(99)00015-2

Gross J., van Dorland H.A., Schwarz F.J., Bruckmaier R.M., 2011. Endocrine changes and liver mRNA abundance of somatotropic axis and insulin system constituents during negative energy balance at different stages of lactation in dairy cows. J. Dairy Sci. 94, 3484-3494, https://doi. org/10.3168/jds.2011-4251

Jacobson D.R., Lindahl I.L., McNeill J.J, Shaw J.C., Doetsch R.N., Davis R.E., 1957. Feedlot bloat studies. II. Physical factors involved in the etiology of frothy bloat. J. Anim. Sci. 16, 515-524, https://doi.org/10.2527/jas1957.162515x

Kuzinski J., Zitnan R., Viergutz T., Legath J., Schweigel M., 2011. Altered $\mathrm{Na}^{+} / \mathrm{K}^{+}$-ATPase expression plays a role in rumen epithelium adaptation in sheep fed hay ad libitum or a mixed hay/concentrate diet. Vet. Med. 56, 36-48, https:// doi.org/10.17221/1571-VETMED

Lee J.H., Budanov A.V., Park E.J. et al., 2010. Sestrin as a feedback inhibitor of TOR that prevents age-related pathologies. Science 327, 1223-1228, https://doi.org/10.1126/ science. 1182228

Liu Q., Wang C., Huang Y.X., Dong K.H., Wang H., Yang W.Z., 2008. Effects of isobutyrate on rumen fermentation, urinary excretion of purine derivatives and digestibility in steers. Arch. Anim. Nutr. 62, 377-388, https://doi. org/10.1080/17450390802327761

Liu Q., Wang C., Huang Y.X., Dong K.H., Yang W.Z., Zhang S.L., Wang $H_{\text {., }}$ 2009. Effects of isovalerate on rumen fermentation, urinary excretion of purine derivatives and digestibility in steers. J. Anim. Physiol. Anim. Nutr. 93, 716-725, https://doi. org/10.1111/j.1439-0396.2008.00861.x

Liu Q., Wang C., Pei C.X. et al., 2014. Effects of isovalerate supplementation on microbial status and rumen enzyme profile in steers fed on corn stover based diet. Livest. Sci. 161, 60-68, https://doi.org/10.1016/j.livsci.2013.12.034

Liu Q., Wang C., Zhang Y.L., Pei C.X., Zhang S.L., Li H.Q., Guo G., Huo Y.J., Yang W.Z., Wang H., 2016. Effects of 2-methylbutyrate supplementation on growth performance and ruminal development in pre- and post-weaning dairy calves. Anim. Feed Sci. Technol. 216, 129-137, https://doi. org/10.1016/j.anifeedsci.2016.03.028

Lohakare J.D., Pattanaik A.K., Khan S.A., 2006. Effect of dietary protein levels on the performance, nutrient balances, metabolic profile and thyroid hormones of crossbred calves. Asian-Australas. J. Anim. Sci. 19, 1588-1596, https://doi. org/10.5713/ajas.2006.1588
Maekawa M., Beauchemin K.A., Christensen D.A., 2002. Chewing activity, saliva production, and ruminal $\mathrm{pH}$ of primiparous and multiparous lactating dairy cows. J. Dairy Sci. 85, 1176-1182, https://doi.org/10.3168/jds.S0022-0302(02)74180-5

NRC (National Research Council), 2001. Nutrient Requirements of Dairy Cattle. $7^{\text {th }}$ Revised Edition. The National Academies Press. Washington, DC (USA), https://doi.org/10.17226/9825

Pivonello C., Negri M., De Martino M.C. et al., 2016. The dual targeting of insulin and insulin-like growth factor 1 receptor enhances the mTOR inhibitor-mediated antitumor efficacy in hepatocellular carcinoma. Oncotarget 7, 9718-9731, https:// doi.org/10.18632/oncotarget.6836

Russell J.B., Wilson D.B., 1996. Why are ruminal cellulolytic bacteria unable to digest cellulose at low pH? J. Dairy Sci. 79, 15031509, https://doi.org/10.3168/jds.S0022-0302(96)76510-4

Russell J.B., O'Connor J.D., Fox D.G., Van Soest P.J., Sniffen C.J., 1992. A net carbohydrate and protein system for evaluating cattle diets: I. Ruminal fermentation. J. Anim. Sci. 70, 35513561, https://doi.org/10.2527/1992.70113551x

SAS, User's Guide: Statistics, Version 9 Edition., 2002. Statistical Analysis Systems Institute, Cary, NC (USA)

Smith J.M., Van Amburgh M.E., Díaz M.C., Lucy M.C., Bauman D.E., 2002. Effect of nutrient intake on the development of the somatotropic axis and its responsiveness to $\mathrm{GH}$ in Holstein bull calves. J. Anim. Sci. 80, 1528-1537, https://doi. org/10.2527/2002.8061528x

Van Soest P.J., Robertson J.B., Lewis B.A., 1991. Methods for dietary fiber, neutral detergent fiber and non-starch polysaccharides in relation to animal nutrition. J. Dairy Sci. 74, 3583-3597, https://doi.org/10.3168/jds.S0022-0302(91)78551-2

Wang C., Liu Q., Zhang Y.L., Pei C.X., Zhang S.L., Wang Y.X., Yang W.Z., Bai Y.S., Shi Z.G., Liu X.N., 2015. Effects of isobutyrate supplementation on ruminal microflora, rumen enzyme activities and methane emissions in Simmental steers. J. Anim. Physiol. Anim. Nutr. 99, 123-131, https://doi. org/10.1111/jpn.12191

Wang C., Liu Q., Zhang Y.L., Pei C.X., Zhang S.L., Guo G., Huo W.J., Yang W.Z., Wang H., 2017. Effects of isobutyrate supplementation in pre- and post-weaned dairy calves diet on growth performance, rumen development, blood metabolites and hormone secretion. Animal 11, 794-801, https://doi. org/10.1017/S1751731116002093

Williams C.H., David D.J., lismaa O., 1962. The determination of chromic oxide in faeces samples by atomic absorption spectrophotometry. J. Agric. Sci. 59, 381-385, https://doi. org/10.1017/S002185960001546X

Zhao G.-Y., Sun Y.-B., 2010. Effects of volatile fatty acids on IGF-I, IGFBP-3, GH, insulin and glucagon in plasma, and IGF-I and IGFBP-3 in different tissues of growing sheep nourished by total intragastric infusions. Asian-Australas. J. Anim. Sci. 23, 366-371, https://doi.org/10.5713/ajas.2010.90355 